\title{
(E)-2-benzylidenecyclanones: part XV. stereochemistry of reaction of 2-arylidenecyclopentanones with dithiocarbamic acid
}

\begin{abstract}
The reaction of (E)-2-arylidenecyclopentanones (1a-c) with dithiocarbamic acid in acidic medium has been investigated. In the reactions taking place under mild acid conditions 4-aryl-7a-hydroxy-4,4a,5,6,7,7a-hexahydrocyclopenta[d] ${ }^{1-3}$ thiazine$2(1 \mathrm{H})$-thiones $(2 \mathrm{a}-\mathrm{c})$ were formed. It was found that the compounds $(2 \mathrm{a}-\mathrm{c})$ belonged to the same isomer series: the cyclopentane and the 1,3-thiazine rings are cis-fused and the 4-aryl group is in trans position to the annelated $\mathrm{H}-4 \mathrm{a}$ atom. ${ }^{1} \mathrm{H}$ NMR investigations proved the $\mathrm{N}$-inside conformation of the compounds in solution where the 4-aryl group takes a pseudoequatorial position.
\end{abstract}

Keywords: enones, dithiocarbamic acid, michael addition, 1,3-thiazine-2(1h)thione, conformational analysis, $\mathrm{n}$-inside conformation
Volume 2 Issue I - 2018

\author{
Pál Perjési, ' András Földesi, ${ }^{2}$ Gyula Batta ${ }^{3}$ \\ 'Institute of Pharmaceutical Chemistry, University of Pécs, Pécs, \\ Hungary \\ ${ }^{2}$ Department of Cell and Molecular Biology, Uppsala University, \\ Sweden \\ ${ }^{3}$ Department of Organic Chemistry, University of Debrecen, \\ Hungary
}

\begin{abstract}
Correspondence: Pál Perjési, PhD Institute of Pharmaceutical Chemistry, University of Pécs, H-7624 Pécs, Hungary, Tel +36 72 503-626, Fax +36 72 503-627, Email pal.perjesi@gytk.pte.hu

Received: December 14, 2017| Published: January 03, 2018
\end{abstract}

Abbreviations: NMR, nuclear magnetic resonance; TLC, thin layer chromatography; MP, melting point

\section{Introduction}

The reaction of $\alpha, \beta$-unsaturated carbonyl compounds with carbonic acid derivatives is a method frequently used for the synthesis of pyrimidines and 1,3-thiazines. ${ }^{1-7}$ Although these methods have been mentioned in the literature for a long time, there are only a few examples of investigation on the mechanism and the stereochemistry of reactions. Based on earlier examinations ${ }^{5-7}$ reaction of $\alpha, \beta-$ unsaturated carbonyl compounds with dithiocarbamic acid (Michaelrecation) is a suitable synthetic pathway for studying the reaction leading to the formation of 1,3-thiazines.

In one of our earlier works, reaction of para-substituted chalcones and dithiocarbamic acid was studied. It was found that the reaction results in formation either open-chain or cyclic adducts depending on the substitution pattern of the aromatic rings of the chalcones. ${ }^{6}$ Later, we have reported on stereochemical analysis of reactions with dithiocarbamic acid of (E)-2-benzylidenecyclohexanones ${ }^{8,9}$ and some (E)-2-benzylidene-1-benzocylanones. ${ }^{10}$ Reactions of the investigated compounds led to formation of cyclic ${ }^{8,9}$ or open chain ${ }^{10}$ adducts. Stereochemistry of the formed adducts were found to be determined by both the structure of the $\alpha, \beta$-unsaturated carbonyls and the reaction conditions.

Addition reaction with dithiocarbamic acid of (E)-2benzyldenecylohexanones resulted in formation of isomeric cyclic adducts. ${ }^{8,9}$ In such a case three new chiral centers are formed allowing formation of four diastereomeric pairs. In the reactions formation of three of the possible diastereomers could be detected and characterized. Stereochemistry of cyclization of the primary (Michael-type) adducts was determined by the preferred conformation of the forming bicyclic saturated heterocycles. ${ }^{89}$ The aim of the present work is to investigate the structure and stereochemistry of the dithiocarbamic acid adducts of the five-membered analogue (E)-2-arylidenecyclopentanones (1ac).

\section{Experimental}

M.p.'s were determined With a Boetius hot plate apparatus, and are uncorrected. IR spectra were measured with a SPECORD 75 IR instrument. $60 \mathrm{MHz}{ }^{1} \mathrm{H}$ NMR spectra were obtained with a PerkinElmer R-12 spectrometer, and $200 \mathrm{MHz}$ spectra with a Bruker WP $200 \mathrm{SY}$ spectrometer for DMSO- $\mathrm{d}_{6}$ solutions operating at $35^{\circ} \mathrm{C}$ and $25^{\circ} \mathrm{C}$, respectively. Chemical shifts are reported as $\delta$ values in ppm. downfield from internal tetramethylsilane, and coupling constants in $\mathrm{Hz}$. The starting 2-arylidenecyclopentanones (1a-c) were prepared by aldol condensation. All the compounds have (E) configuration. ${ }^{11}$

The progress of the reactions as well as the purity of the isolated compounds was checked by TLC performed on Kieselgel GF 254 plates (Merck) using benzene: ethanol 4:1 (v/v) as eluent. The isomeric composition of the crude products was determined by ${ }^{1} \mathrm{H}$ NMR spectroscopy $(60 \mathrm{MHz})$ based on investigation of the wellseparated $\mathrm{H}-4 \mathrm{a}$ signals. Elemental analyses were performed at the Department of Organic Chemistry, Eötvös Loránd University, Budapest (Hungary).

\section{General procedures for addition reactions}

A solution of 0.075 mole ammonium dithiocarbamate ${ }^{12}$ in $150 \mathrm{ml}$ $50 \%$ methanol was acidified by adding $25 \mathrm{ml}$ of $6,5 \mathrm{~N}(0.165 \mathrm{~mole})$ hydrochloric acid. Both solutions were precooled to $-5^{\circ} \mathrm{C}$ and the temperature was maintained at $-5^{\circ} \mathrm{C}$ through the addition 5 minutes which was carried out with starring. To this solution of dithiocarbamic 
acid a cooled methanolic solution of 0.03 mole unsaturated ketone (1ac) was added under continuous cooling and stirring, and the reaction mixture was stirred at $-5^{\circ} \mathrm{C}$ for additional $4-5$ hours. After completing the reaction (TLC), the reaction mixture was diluted with water, the forming precipitate was filtered off, washed with water, and dried in vacuum exiccator. The crude products were purified by crystallization from methanol to give colorless crystals (2a-c).

4-Phenyl-7a-hydroxy-4,4a,5,6,7,7a-hexahydrocyclopenta[d][I,3]thiazine-2(I H)-thione(2a): This was formed in $72 \%$ yield, m.p. $158-161^{\circ}$ C. (Found: C, 58.59; H, 5.41; S, 24.31 . $\mathrm{C}_{13} \mathrm{H}_{15} \mathrm{NOS}_{2}$ requires $\left.\mathrm{C}, 58.83 ; \mathrm{H}, 5.70 ; \mathrm{S}, 24.16 \%\right) ; v_{\max }$ (KBr pellet) 3500-3175 (OH+NH), $3130(\mathrm{NH}), 2960$ (aliphatic), and 1500 (aromatic); $\delta_{\mathrm{H}}(200 \mathrm{MHz}), 10.65(1 \mathrm{H}, \mathrm{s}, \mathrm{NH}), 7.48-7.25(5 \mathrm{H}, \mathrm{m}, \mathrm{Ph}), 6.65$ $(1 \mathrm{H}, \mathrm{s}, \mathrm{OH}), 4.96\left(1 \mathrm{H}, \mathrm{d},{ }^{3} \mathrm{~J}_{4,4} 3.3 \mathrm{~Hz}, 4-\mathrm{H}\right), 2.38\left(1 \mathrm{H}, \mathrm{ddd},{ }^{3} \mathrm{~J}_{4,}, 5,8 \mathrm{~Hz}\right.$, $\left.{ }^{3} \mathrm{~J}_{4 \mathrm{a}}, 5,11 \mathrm{~Hz}, 4 \mathrm{a}-\mathrm{H}\right), 2.38\left(1 \mathrm{H}, \mathrm{ddd},{ }^{3} \mathrm{~J}_{7},{ }^{\prime}, 13.3 \mathrm{~Hz},{ }^{3} \mathrm{~J}_{7},{ }^{\prime}, 6{ }^{\prime} 8.4 \mathrm{~Hz},{ }^{3} \mathrm{~J}_{7},{ }^{\prime}, 6\right.$, $\left.2.3 \mathrm{~Hz}, 7^{\prime}-\mathrm{H}\right)$, and $1.89-1.36$ (5H, m, aliphatic).

4-(4'-Methylphenyl)-7a-hydroxy-4,4a,5,6,7,7a-hexahydrocyclopenta[d] $[\mathrm{I}, 3]$ thiazine-2(IH)-thione (2b): This was formed in $79 \%$ yield, m.p. $165-167^{\circ} \mathrm{C}$. (Found: C, 59.92; H, 6.07; $\mathrm{S}, 23.19 . \mathrm{C}_{14} \mathrm{H}_{17} \mathrm{NOS}_{2}$ requires $\left.\mathrm{C}, 60,18 ; \mathrm{H}, 6.13 ; \mathrm{S}, 22,95 \%\right) ; v_{\max }$ (KBr pellet) 3550-3220 (OH+NH), $3160(\mathrm{NH}), 2975$ (aliphatic), and 1510 (aromatic).
4-(4'-Methoxyphenyl)-7a-hydroxy-4,4a,5,6,7,7a-hexahydrocyclopenta[d] [I,3] thiazine-2(IH)-thione (2c): This was formed in $81 \%$ yield, m.p. $160-163^{\circ} \mathrm{C}$. (Found: C, 59.14; H, 5.96; S, 21.64. $\mathrm{C}_{14} \mathrm{H}_{17} \mathrm{NO}_{2} \mathrm{~S}_{2}$ requires $\mathrm{C}$, 56.92; H. 5, 80; S, 21, 71\%); $v_{\max }(\mathrm{KBr}$ pellet) 3500-3200 (OH+NH), $3145(\mathrm{NH}), 2950$ (aliphatic), and 1510 (aromatic).

\section{Results and discussion}

Reaction of (E)-2-arylidenecyclopentanones (1a-c) with dithiocarbamic acid was carried out in a hydrochloric methanol solution at $-5^{\circ} \mathrm{C}$. In the reactions taking place under acid conditions ${ }^{8,9}$ formation of compounds (2a-c) were obtained (Figure 2).

In order to investigate the stereo chemical outcome of the reactions the crude products were analyzed by ${ }^{1} \mathrm{H}$ NMR $(60 \mathrm{MHz})$ spectroscopy. The analyses showed formation only one diastereoisomer in each case. Examination of the IR and the ${ }^{1} \mathrm{H}$ NMR spectra of the isolated compounds (2a-c) showed the adducts to exist in cyclic form both in the solid state and in solution. Thus three asymmetric centers are formed in the course of the reaction, which makes formation of four pairs of diastereoisomers possible. ${ }^{1} \mathrm{H}$ NMR data indicated the compounds to be stereohomogenous products having the same stereochemistry (Table 1).

Table I 'H NMR chemical shifts (ppm) and coupling constants $(\mathrm{Hz})$ of compounds $(2 \mathrm{a}-\mathrm{c})^{\mathrm{a}}$

\begin{tabular}{lllllllll}
\hline Compound & $\mathbf{N H}^{\mathrm{b}}(\mathbf{s})$ & Aromatic $(\mathbf{m})$ & $\mathbf{O h}^{\mathbf{b}}(\mathbf{s})$ & $\mathbf{H}-\mathbf{4}(\mathbf{d})$ & $\mathbf{M e}$ or $\mathbf{M e O}(\mathbf{s})$ & Aliphatic & $\mathbf{H}_{-4 \mathbf{a}^{\mathbf{c}}}$ & ${ }^{\mathbf{3} \mathbf{4}, \mathbf{4 a}} \mathbf{a}^{\mathbf{d}}$ \\
\hline$(2 \mathrm{a})$ & 10.65 & $7.50-7.25$ & 6.55 & 4.95 & - & $2.60-1.30$ & 2.35 & 3.5 \\
$(2 \mathrm{~b})$ & 10.65 & $7.45-7.20$ & 6.65 & 4.95 & 2.4 & $2.55-1.30$ & 2.35 & 3.5 \\
$(2 \mathrm{c})$ & 10.6 & $7.50-6.90$ & 6.59 & 5 & 3.85 & $2.55-1.28$ & 2.4 & 3.5 \\
\hline
\end{tabular}

\section{aDetermined at $60 \mathrm{MHz}$}

'Signal disappears on the addition of $\mathrm{D}_{2} \mathrm{O}$

'Determined by double-resonance experiment

In $\mathrm{Hz}$

Since the exact determination of the configuration of asymmetric centers could not be unequivocally solved only on the basis of the ${ }^{1} \mathrm{H}$ NMR data, the steric structure of (2a) was established by X-ray diffraction. X-ray analysis of the compound showed the cyclopentane and the 1,3-thiazine rings being cis-fused and the 4-phenyl group in trans position to the annelated H-4a atom. ${ }^{13}$ These results can be explained by trans-addition of dithiocarbamic acid onto the polarized carbon-carbon double bound followed by a conformation-driven cyclization of the open-chain adduct. ${ }^{9}$ The stereochemistry of the isolated adduct is the same as that of obtained in similar reaction of $(\mathrm{E})$ 2-benzylidenecyclohexanone under less acidic conditions. ${ }^{89}$ On the other hand, the stereochemistry of the obtained adducts is opposite to that observed in the similar reaction of (E)-2-benzylidene-1-indanonethe benzocondensed analogue of (E)-2-benzylidenecyclopentanone (1a) -with dithiocarbamic acid. ${ }^{14}$

With full knowledge of configuration of (2a), the two possible conformations ( $\mathrm{N}$-inside and $\mathrm{N}$-outside) of the obtained compounds are shown in Figure 1. Taking these conformations into account the chemical shift and multiplicity of the $4-\mathrm{H}$ and the $\mathrm{H}-4$ a protons and that of the $\mathrm{OH}$ signal are determinative spectroscopic parameters. ${ }^{15}$

As it is shown in Table 1, the ${ }^{1} \mathrm{H}$ NMR data of the corresponding protons are almost the same in the three products. Although the ${ }^{1} \mathrm{H} N M R$ data suggest that the compounds have monoconformational behavior, these results are not enough for distinguishing the conformers. Namely, the only valuable fact considering these conformations is the splitting of the $\mathrm{H}-4$ and the $\mathrm{H}-4 \mathrm{a}$ protons. This fact, however, does not allow distinguishing the conformers since the dihedral angle of the $\mathrm{H}-4$ and the $\mathrm{H}-4 \mathrm{a}$ protons (based on the Dreiding models) is about $45^{\circ}$ in both the $\mathrm{N}$-inside and the $\mathrm{N}$-outside conformers (Figure 1).

The conformational relations were determined by examination of (2a) carried out at $200 \mathrm{MHz}$. In the spectrum recorded at $200 \mathrm{MHz}$ the H-4a signal appears separately ( $\delta 2.38)$. The coupling constants measured for the H-4a signal render it possible to investigate the conformations. The molecular model shows that the dihedral angles between the $\mathrm{H}-4 \mathrm{a}$ and the $\mathrm{C}-5$ methylene protons in the N-outside conformer are $\sim 30^{\circ}$ and $\sim 90^{\circ}$, respectively. The measured coupling constants of $8 \mathrm{~Hz}$ and $11 \mathrm{~Hz}$ rule out this conformer, but they fit in well with the angles of $\sim 30^{\circ}$ and $\sim 180^{\circ}$ in the $\mathrm{N}$-inside conformer (Figure $1)$.

With the purpose of further examinations of the conformational relations ${ }^{1} \mathrm{H}-{ }^{1} \mathrm{H}$ N.O.E. investigations were carried out, the result of which are summarized in Table 2. The most remarkable experimental result is the NOE effect measurable well between the $\mathrm{H}-4$ and $\mathrm{OH}$ protons, which support their spatial closeness. These ${ }^{1} \mathrm{H}$ NMR investigations also proves the dominant $\mathrm{N}$-inside conformation in solution where the 4-aryl group takes a pseudoequatorial position. 
Similar observations-predominance of this type conformation for bicyclic saturated heterocycles with unsubstituted N-1 atom -were made with cyclopentane- and cyclohexane-fused 1,3-oxazines and 1,3-thiazines with related structures. ${ }^{16}$

Addition of sulfur nucleophiles onto unsaturated carbonyl compounds has not only synthetic but bioorganic importance as well. Reduced glutathione (GSH) is the most abundant cytosolic thiol

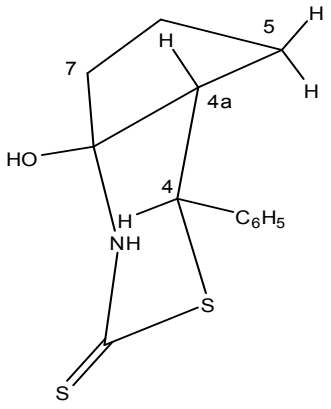

Figure I $\mathrm{N}$-inside and $\mathrm{N}$-outside conformations of $2 \mathrm{a}$.<smiles>O=C1CCC/C1=C\Br</smiles>

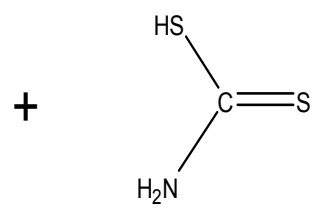

Figure 2 Reaction of (E)-2-arylidinecyclopentanones with dithiocarbamic acid

Ar: (a) $\mathrm{C}_{6} \mathrm{H}_{5}$, (b) $4-\mathrm{CH}_{3}-\mathrm{C}_{6} \mathrm{H}_{4}$, (c) $4-\mathrm{CH}_{3} \mathrm{O}-\mathrm{C}_{6} \mathrm{H}_{4}$

Table 2 NOE data for compound $(2 \mathrm{a})^{\mathrm{a}}$

\begin{tabular}{ll}
\hline $\begin{array}{l}\text { Hydrogen atom irradiated } \\
(\delta)\end{array}$ & Observed enhancement (\%) \\
\hline $\mathrm{H}-4(4.95)$ & $\mathrm{OH}(+10), \mathrm{H}-4 \mathrm{a}(+12)$ \\
$\mathrm{OH}(6.55)$ & $\mathrm{H}-4(+10)$ \\
$\mathrm{NH}(10.65)$ & $\mathrm{OH}(+6), \mathrm{H}-7{ }^{\prime}(+6)$ \\
\hline
\end{tabular}

a Determined at $200 \mathrm{MHz}$ in DMSO- $d_{6}$ solution.

\section{Conclusion}

Stereochemical analysis of reaction products of (E)-2arylidenecyclopentanones (1a-c) and dithiocarbamic acid showed the reactions to yield stereohomogeneous 4aryl-7a-hydroxy4,4a,5,6,7,7a- hexahydrocyclopenta[d] [1,3]thiazine-2(1H)-thiones (2a-c). Combined X-ray and ${ }^{1} \mathrm{H}$ NMR analyses proved that the 1,3-thiazine rings are cis-fused and the 4-aryl group is in trans position to the annelated $\mathrm{H}-4 \mathrm{a}$ atom. The compounds adopt the energetically more preferred $\mathrm{N}$-inside conformation where the 4-aryl group takes a pseudoequatorial position. The results indicate importance of ring size of (E)-2-benzylidenecyclanones in stereochemistry of Michael-type addition of dithiocarbamic acid. Stereochemistry of cyclization was found to be determined by the preferred $\mathrm{N}$-inside conformation of the cis-anellated bicyclic products.

\section{Acknowledgements}

The present scientific contribution is dedicated to the $650^{\text {th }}$ playing important role in protection of cells against electrophilesinitiated damages. ${ }^{17}$ Earlier we have demonstrated that chalcones (open-chain $\alpha, \beta$-unsaturated carbonyls) $)^{18}$ and cyclic chalcone analogues ${ }^{19,20}$ possess intrinsic reactivity towards GSH resulting in formation of the expected adducts. Accordingly, thiol reactivity of $\alpha, \beta$-unsaturated carbonyl compounds is a basis of one of the biotransformation pathways of this kind of xenobiotics.
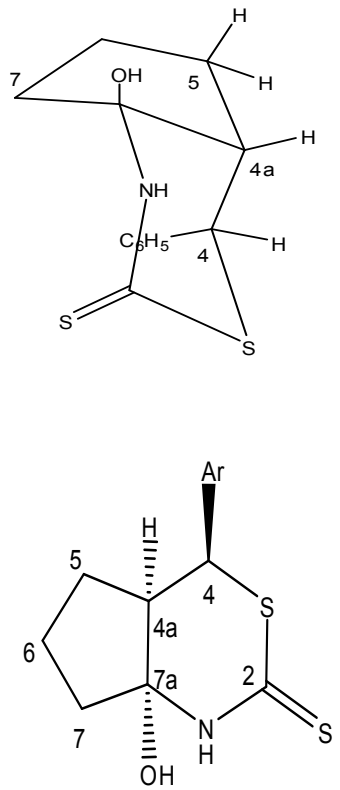

anniversary of the foundation of the University of Pécs, Hungary. This study was supported by the University of Pécs, Faculty of Medicine Research Fund (AOK-KA-2013/20).

\section{Conflict of interest}

The author declares no conflict of interest.

\section{References}

1. Zigeuner G, Bayer M, Paltauf F, et al. Über Heterocyclen, 15. Mitt. 2Oxo- bzw. 2-Thiono-6-phenyltetrahydropyrimidine. Monatsh Chem. 1967;98(1):22-33.

2. Lóránd T, Szabó D, Neszmélyi A. Reactions of Mono-and Diarylidenecycloalkanones with Thiourea and Ammonium Thiocyanate. Acta Chim Acad Sci Hung. 1977;93(1):51-65.

3. Zimmermann R. Zur Reaktion $\alpha . \beta$-ungesättigter Ketone mit Thioharnstoff. Angew Chem. 1963;75(21):1025.

4. Lóránd T, Szabó D. Synthesis of 4-Aryl-2-imino-1,2,5,6,7,8-hexahydro-4H-3,1-benzothiazine Salts and 4-Aryl-2-imino-1,2,4,5,6,7hexahydrocyclopenta[d][1,3] thiazine Salts. Acta Chim Acad Sci Hung. 1977;94(4):363-371.

5. Cain EN, Warrener RN. Preparation of 1,3-thiazines:Sulphur analogues of nucleic acid pyrimidine bases. Aust J Chem. 1970;23(1):51-72.

6. Perjési P, Szabó D, Földesi A. Synthesis of 4,6-diaryl-2,3-dihydro-6H-1,3-thiazine-2-thiones by the reaction of chalcones with dithiocarbamic acid. Acta Chim Hung. 1986;122(2):119-125.

7. Lévai A. Synthesis of exocyclic $\alpha, \beta$-unsaturated ketones. Arkivok. $2004 ; 7: 15-33$. 
8. Perjési P, Szabó D, Batta Gy, et al. The stereochemistry of reaction of $2-$ benzylidenecyclohexanone with dithiocarbamic acid. Tetrahedron Lett. 1987;28(5):571-572.

9. Perjési P, Földesi A, Batta Gy, et al. Synthesis and stereochemistry of saturated and partially saturated 4-aryl $-4 \mathrm{H}-3,1-$ benzothiazine $-2(1 \mathrm{H})$ thiones. Chem Ber. 1989;122(4):651-656.

10. Perjési P, Batta G, Földesi A. Reaction of benzylidenebenzocyclanones with dithiocarbamic acid and thiourea. Monatsh Chem. 1994;125(4):433-499.

11. Sohár P, Csámpai A, Perjési P. Synthesis and structure of some E-ferrocenemethylenecycloalkanones and their benzylidene analogs. Arkivok. 2003;5:114-120.

12. Acenaphthenequinone. Organic Synthesis. USA: Wiley and Sons Inc; 1955. 3:763.

13. Argay Gy, Kálmán A, Perjési P, et al. Structure of 7a-hydroxy-4-phenyl $-1,2,4,4 \mathrm{a}, 5,6,7,7 \mathrm{a}-$ octahydrocyclopenta[d][1,3]thiazine-2-thione. Acta Cryst C. 1987;43:324-326.

14. Kálmán A, Argay G, Perjési P, et al. Structure of $\left(2 R^{*}, 8 R^{*}\right)-2-[\alpha-$ (thiocarbamoylthio)benzyl]indan-1-one. Acta Cryst C. 1988;44:1955-1957.
15. Sohár P, Bernáth G. Stereochemical studies-XIV:Cyclic amino alcohols and related compounds-VII. Org Magn Reson. 1973;5(3):159-160.

16. Fülöp F, Bernáth G, Pihlaja K. Synthesis, stereochemistry and transformations of cyclopentane-, cyclohexane-, cycloheptane-, and cyclooctane-fused 1,3-oxazines, 1,3-thiazines, and pyrimidines. Adv Heterocycl Chem. 1998;69:349-477.

17. Cacciatore I, Cornacchia C, Pinnen F, et al. Prodrug approach for increasing cellular glutathione levels. Molecules. 2010;15(3):1242-1264.

18. Bernardes A, Pérez CN, Mayer M, et al. Study of Reactions of Two Mannich Bases Derived of 4'-Hydroxychalcones with Glutathione by RP-TLC, RP-HPLC and RP-HPLC-ESI-MS Analysis. J Braz Chem Soc. 2017;28(6):1048-1062.

19. Perjési P, Maász G, Reisch R, et al. (E)-2-Benzylidenebenzocyclanones: Part VII. Investigation of the conjugation reaction of two cytotoxic cyclic chalcone analogues with glutathione: an HPLC-MS study. Monatsheft Chem. 2012;143(8):1107-1114.

20. Rozmer ZS, Marton E, Perjési P. (E)-2-benzylidenebenzosuberone derivatives with calf thymus DNA by TLC and UV-Vis methods, a DNA cleavage study. Med Chem Res. 2017;26(9):2172-2179. 